\title{
Act limiting nuclear liability heads for home strait
}

\section{Washington}

THE Price-Anderson Act, the law that nuclear power plant accident, is lurching towards renewal in Congress. Attempts to revive it before it expired last summer failed, as did those shortly afterwards. But now the Senate has passed and will shortly send to the House of Representatives its version of the new legislation, and observers from industry, environmental groups and congressional staff agree that final passage appears inevitable.

The Price-Anderson Act was created in 1954 to protect a fledgling nuclear indusevent of a nuclear accident. The law created a pool into which all nuclear power plant operators would make contributions in the event of an accident. Liability limits crept up over the years, so that by the time the act expired last August utilities were required to carry $\$ 160$ million in insurance for each power plant they owned, and to be prepared to contribute $\$ 5$ million to the coverage pool. That amounted to a total industry liability of around $\$ 700$ million, far below even the most conservative damage estimates for any major accident.

The Senate version of Price-Anderson would raise the contribution to $\$ 63$ million per reactor, amounting to an industrywide liability of more than $\$ 7,000$ million, a tenfold increase. Environmental lobbies have seen this as a tremendous victory, and the industry - aware that liability limits had been unreasonably low in the past - was happy to stave off unlimited liability that some had been pushing for.

Price-Anderson also covers Department of Energy contractors whose work defines industry liability in the event of a try from devastating liability claims in the

deals with fissionable materials. Without Price-Anderson, DoE contractors were threatening to refuse to sign contracts. But last year, the University of California agreed to continue to operate the DoE national laboratories at Livermore, Los Alamos and Berkeley under the terms of the War Powers Act, and a crisis was averted (see Nature 330, 103; 1987). The next major problem for DoE will be to find a contractor to run the weapons production reactor at Savannah River. DuPont has already told DoE it wants out, but now that Price-Anderson appears likely to gain approval, finding a replacement should be easier. Contractors are also covered up to about $\$ 7,000$ million in the event of an accident, but the government picks up the tab.

Environmental groups had sought to make contractors liable for damages if negligence contributed to an accident. But Price-Anderson will in essence retain its 'no-fault' approach, although the Senate agreed to permit $\mathrm{DoE}$ to assess penalties against contractors found negligent, in much the same way that the Nuclear Regulatory Commission may fine nuclear power plant operators.

An odd sticking-point may hold up final passage of the bill. In the Senate, an amendment was added that would extend Price-Anderson coverage to manufacturers of radiopharmaceuticals. That industry has had problems obtaining insurance, and some saw Price-Anderson as a convenient vehicle for providing that coverage. But the leadership in the House of Representatives does not agree, and a battle may be fought in conference between the two houses over this seemingly irrelevant point.

Joseph Palca

\section{Trees to benefit from Third World debt}

\section{Washington}

The World Wildlife Fund (WWF) last week consummated a 'debt-for-nature' deal by purchasing $\$ 1$ million of Ecuadorean debt. The move follows an announcement the previous week of a similar arrangement with Costa Rica to the tune of $\$ 3$ million.

Purchasing discounted Latin American debt has suddenly become a popular way of encouraging conservation movements in developing countries, as it can frequently be purchased at a large discount. Last summer, Conservation International purchased $\$ 650,000$ in Bolivian debt for $\$ 100,000$ in exchange for a commitment to declare 3.7 million acres of tropical rain forest as a protected area.

Unlike the Bolivian debt swap, the WWF will give the note it purchased to a non-government conservation organization in Ecuador, Fundacion Natura, which will exchange it through the Central Bank of Ecuador for bonds in local currency. Fundacion Natura will use the interest from the bonds to pay for continuing conservation projects. Bankers Trust Company and Citicorp/Citibank helped to arrange the debt purchase, which came to $\$ 354,500$.

The Costa Rican deal will be similar. Once the debt is purchased, it will be transferred to the Costa Rican National Park Foundation, which will also exchange it for local currency bonds.

Some of the bond proceeds may be used to purchase dry forest land for the proposed Guanacaste National Park.

Joseph Palca

\section{France set to lead Europe?}

\section{Paris}

I $\mathrm{T}$ is paradoxical that the prospect of free trade in Europe from 1992 should stimulate a spirit of nationalism, with echoes of the late President de Gaulle. For this, superficially at least, was the impression conveyed at a morning conference on France's contribution to European science and technology held under the auspices of Prime Minister, Jacques Chirac, on 26 March. But, when electoral politics were put aside, leading researchers and technocrats provided an insight into practical problems confronting international research.

France is a leading supporter of several European 'big science' ventures, but, according to Chirac, needs to increase by 50 per cent its private-sector investment in technology research - equivalent to an extra FF25,000 million ( $£ 2,500$ million) in the next 7 years, in order to compete with West Germany. The way this has been translated in the government's research policy, however, gives little comfort to state-supported basic research. According to Chirac, "a dynamic policy supporting research and innovation is not achieved by voting budget increases for public sector research".

The range of government initiatives to "irrigate" the private sector with fertile young minds otherwise likely to dedicate themselves to basic research in the public sector is now familiar. The emphasis is firmly on tax incentives for research and development, industry-based grants for doctoral training and collaborative research between university and industry, based on 11 national research priorities (see Nature 329, 380; 1987).

While the politicians praised France's role in European research initiatives, those directly involved were more pragmatic. According to Philippe Lazar, president of the co-ordinating committee on medical research, "European cooperation works well in the laboratory, but hardly at all in the domain of communication and information exchange". Lazar wants to see more European science journals and better informed decisionmakers. "Governments should be less concerned with financial returns and should devote more energy to multiplying opportunities for training and exchange at all levels, from researchers to administrators".

"Real research cooperation is easier to imagine than to achieve", says Lazar, who also feels that more effort should be spent on assuring compatibility of research procedures and evaluation of results, particularly in the field of public health, which requires "European-scale investment on a par with big science projects". Peter Coles 